\title{
Genetic Characterization of Resistance to Wheat Stem Rust Race TTKSK in Landrace and Wild Barley Accessions Identifies the rpg4/Rpg5 Locus
}

\author{
Bullo Erena Mamo, Kevin P. Smith, Robert S. Brueggeman, and Brian J. Steffenson
}

First and fourth authors: Department of Plant Pathology, University of Minnesota, St. Paul 55108-6030; second author: Department of Agronomy and Plant Genetics, University of Minnesota, St. Paul 55108-6030; and third author: Department of Plant Pathology, North Dakota State University, Fargo 58108-6050.

Current address of B. E. Mamo: Department of Plant Pathology, University of California, Davis 95616-5270.

Accepted for publication 21 July 2014.

\begin{abstract}
Mamo, B. E., Smith, K. P., Brueggeman, R. S., and Steffenson, B. J. 2015. Genetic characterization of resistance to wheat stem rust race TTKSK in landrace and wild barley accessions identifies the rpg4/Rpg5 locus. Phytopathology 105:99-109.

Race TTKSK of the wheat stem rust pathogen (Puccinia graminis $\mathrm{f}$. sp. tritici) threatens the production of wheat and barley worldwide because of its broad-spectrum virulence on many widely grown cultivars. Sources of resistance against race TTKSK were recently identified in several barley landraces (Hordeum vulgare subsp. vulgare) and wild barley accessions (H. vulgare subsp. spontaneum). The objectives of this study were to characterize the inheritance of resistance to wheat stem rust race TTKSK in four barley landraces (Hv501, Hv545, Hv602, and Hv612) and two wild barley (WBDC213 and WBDC345) accessions, map the resistance genes, and determine the allelic relationships among the genes in these accessions and the previously described rpg4/Rpg5 locus. Resistant accessions were crossed with the susceptible cv. Steptoe and resulting $\mathrm{F}_{3}$ populations were evaluated for resistance to race TTKSK at the seedling stage. Segregation of $\mathrm{F}_{3}$ families in populations involving the resistance sources of Hv501, Hv545, Hv612, WBDC213, and WBDC345 fit a 1:2:1 ratio for homozygous resistant (HR)/segregating (SEG)/homozygous susceptible (HS) progenies (with $\chi^{2}=2.27$ to 5.87 and $P=0.053$ to 0.321 ), indicating that a single gene confers resistance to

race TTKSK. Segregation of $\mathrm{F}_{3}$ families in cross Steptoe/Hv602 did not fit a 1:2:1 ratio (HR/SEG/HS of 20:47:43 with $\chi^{2}=11.95$ and $P=0.003$ ), indicating that more than one gene is involved in imparting resistance to race TTKSK. Bulked segregant analysis using $>1,500$ single-nucleotide polymorphism markers positioned a resistance locus in all six populations on chromosome $5 \mathrm{HL}$ in very close proximity to the known location of the rpg4/Rpg5 complex locus. Allelism tests were conducted by making crosses among resistant accessions Hv501, Hv545, and Hv612 and also Q21861 with the rpg4/Rpg5 complex. No segregation was observed in $\mathrm{F}_{2}$ families inoculated with race TTKSK, demonstrating that all $\mathrm{Hv}$ lines carry the same allele for resistance and that it resides at or very near the rpg4/Rpg5 locus. Phenotype evaluations of the six barley accessions with wheat stem rust race QCCJ revealed resistant infection types (ITs) at a low incubation temperature and susceptible ITs at a high incubation temperature, similar to Q21861, which carries the temperature-sensitive gene rpg4. The accessions also exhibited low ITs against the rye stem rust isolate 92-MN-90, suggesting that they also carry Rpg5. This result was confirmed through molecular analysis, which revealed that all six barley accessions contain the serine threonine protein kinase domain that confers Rpg5 resistance. These results indicate that cultivated barley is extremely vulnerable to African stem rust races such as TTKSK because even these diverse selections of landrace and wild barley accessions carry only one locus for resistance.
\end{abstract}

Stem rust, caused by Puccinia graminis Pers., is one of the most important diseases of wheat, barley, oat, and rye, owing to its ability to completely destroy crops in a short period of time over a large scale. Wheat stem rust, caused by $P$. graminis f. sp. tritici Erikss. \& Henning, attacks both wheat and barley in many regions of the world. Stem rust has caused multiple widespread epidemics in the northern Great Plains region of the United States and Canada, with the most recent occurring in the 1930s and 1950s (36). Losses due to stem rust have been greatly reduced in the Great Plains region of the United States since the late 1950s due to the wide-scale deployment of resistant, early maturing cultivars, and also eradication of barberry (Berberis vulgaris L.), the alternate host of the stem rust pathogen $(19,35)$. Since then, the incidence of new $P$. graminis $\mathrm{f}$. sp. tritici races and epidemics

Corresponding author: B. J. Steffenson; E-mail address: bsteffen@umn.edu

* The $\boldsymbol{e}$-Xtra logo stands for "electronic extra" and indicates that the online version contains two supplemental tables and one supplemental figure.

http://dx.doi.org/10.1094/PHYTO-12-13-0340-R

(c) 2015 The American Phytopathological Society have been very infrequent (35). However, in 1998, a new race of P. graminis f. sp. tritici, now designated as TTKSK (also known as isolate Ug99) was detected in Uganda (32) and later found to be virulent against a widely used resistance $(R)$ gene in wheat $(\operatorname{Sr} 31)$ as well as many other commonly used $R$ genes $(16,32)$. Currently, race TTKSK threatens wheat and barley production worldwide. It is capable of attacking $>90 \%$ of the world's wheat cultivars (40). It is also widely virulent on barley, attacking $>97 \%$ of cultivars grown worldwide (47). Since its detection in Uganda, race TTKSK and its variants have spread to a number of other countries in Africa (Kenya, Ethiopia, Sudan, Tanzania, South Africa, Zimbabwe, Mozambique, and Eritrea) and also the Middle East (Yemen and Iran) $(25,27,31,33,51,53,54)$. Variants in the "Ug99 lineage" are expected to spread to other cereal-producing regions of the world in the near future $(12,40)$.

Although the damaging effects of stem rust, including race TTKSK, can be mitigated by fungicide applications, the extra input costs and potential negative consequences of chemical treatments on the environment warrant the use of host $R$ genes to control stem rust. To date, eight stem rust $R$ genes have been identified in different accessions of barley. Gene Rpgl was identified from barley accessions 'Chevron' (CIho 1111) and 'Peatland' 
(CIho 5267) $(30,39)$, is effective against most wheat stem rust races, and has protected barley from significant stem rust losses for $>70$ years (44). In another genetic study conducted with Peatland, Fox and Harder (10) identified RpgU in addition to Rpg1. However, TTKSK and other related African races are highly virulent on Rpg1. Genes Rpg2 and Rpg3 were identified from the accessions 'Hietpas-5' (CIho 7124) (28) and 'PI 382313' $(14,15)$, respectively, and, like $R p g 1$, are not completely effective against race TTKSK (47). The recessive stem rust $R$ gene rpg4 was identified in breeding line 'Q21861' ('PI 584766') and confers resistance to race QCCJ (17). More recently, a recessive stem rust $R$ gene (rpg6) was identified in '212Y1', a barley line with an introgression of Hordeum bulbosum L. chromatin (9).

Other $R$ genes were described based on their reaction to the rye stem rust pathogen ( $P$. graminis $\mathrm{f}$. $\mathrm{sp}$. secalis). The dominant $R$ gene Rpg5 (initially designated $R p g Q$ ) was discovered in Q21861 $(4,50)$. Gene Rpg5 is tightly linked to rpg4 and is located on the long arm of barley chromosome $5 \mathrm{H}(4,6)$. A recessive gene designated as $r p g B H$ also confers resistance to rye stem rust and was described from 'Black Hulless' (CIho 666) (43).

In an expression quantitative trait loci (eQTL) study of the barley population Q21861/SM89010 (Q/SM) infected with $P$. graminis $\mathrm{f}$. sp. tritici race TTKSK at the adult plant stage in the field, Moscou et al. (24) identified a chromosome 2H trans-eQTL that enhances resistance through transcriptional suppression of many genes. At seedling stage, the major effect locus identified was rpg4/Rpg5 (Rpg-TTKSK) on chromosome 5H. Zhou et al. (55) conducted an association mapping study of U.S. barley breeding germplasm to race TTKSK at the adult plant stage in the field and identified two QTL: one on chromosome $7 \mathrm{H}$ and the other on chromosome $5 \mathrm{H}$, distantly proximal to rpg4/Rpg5. Given that rpg4/Rpg5 is the only effective locus against race TTKSK (47), it is important to identify and genetically characterize new sources of resistance and transfer their genes into commercial cultivars.

The evaluation of a worldwide collection of barley germplasm identified a number of sources of seedling and adult plant resistance to race TTKSK in the Hordeum gene pool, comprising cultivars, landraces, and wild barley accessions (47) (B. Steffenson, unpublished data). Some of the most resistant accessions included landraces $(H$. vulgare subsp. vulgare) from Switzerland and also accessions of wild barley ( $H$. vulgare subsp. spontaneum) from the Wild Barley Diversity Collection (WBDC) (46). Six of these resistant barley accessions were chosen for detailed study to elucidate the genetic basis of race TTKSK resistance so as to enable more efficient use in breeding. Thus, the specific objectives of this study were to (i) characterize the inheritance of resistance to race TTKSK in landrace and wild barley accessions at the seedling stage through biparental mapping, (ii) determine the chromosomal locations of the $R$ genes, and (iii) elucidate the allelic relationships among the $R$ genes in these accessions and the previously described rpg4/Rpg5 complex locus.

\section{MATERIALS AND METHODS}

Plant materials. Six Hordeum accessions exhibiting seedling or adult resistance to race TTKSK were crossed with susceptible 'Steptoe' (CIho 15229) barley to develop mapping populations for genetic analysis (Table 1). Four of the accessions (Hv501, Hv545, Hv602, and Hv612) were landraces originally collected from the alpine regions of eastern Switzerland (Canton Graubünden), a country previously known to be a source of stem-rust-resistant barley germplasm (44). Seed was donated by the Station federale de recherches en production vegetale de Changins in Nyon, Switzerland, courtesy of Geert Kleijer. Selection of these four accessions from a total collection of 74 landraces was based on their genetic diversity, as revealed by 12 simple sequence repeat (SSR) markers (P. Olivera, unpublished data); geographic location within Graubünden; and resistant stem rust phenotype. The two other accessions (WBDC213 and WBDC345) investigated were wild barley collected from Samarkand and Kashkadarya provinces of Uzbekistan, respectively (Table 1). These accessions are part of the WBDC (46), provided by the International Center for Agricultural Research in the Dry Areas in Aleppo, Syria, courtesy of Jan Valkoun.

Planting, inoculation, and incubation of plants. $F_{2}$ plants from the crosses were not evaluated for race TTKSK because of space limitations for increasing to the next generation within the Biosafety Level-3 (BSL-3) Containment Facility at the University of Minnesota in St. Paul. Thus, 25 to 35 plants of each $F_{3}$ family were evaluated at the seedling stage for response to race TTKSK. The tests were conducted inside the BSL-3 facility during the winter months. $\mathrm{F}_{3}$ families and parents were planted in plastic pots ( 7.6 by 7.6 by $10.8 \mathrm{~cm}$ [length by width by height]) filled with a 50:50 mix of steam-sterilized native soil and Metro-Mix 200 (Sun Gro Horticulture, Quincy, MI) (vermiculite, sphagnum peat moss, perlite, dolomitic limestone, and a wetting agent). After planting, all pots were watered and fertilized with Osmocote controlled-release fertilizer 14-14-14 (Scott's Company, Marysville, OH) (1.4 g/pot) and Peters Dark Weather fertilizer 15-0-15 (Scott's Company) ( $\approx 40 \mathrm{~g} /$ liter at $1 / 16$ dilution). Populations derived from wild barley accessions were kept at $4{ }^{\circ} \mathrm{C}$ for 2 weeks to break dormancy and facilitate uniform emergence and growth prior to inoculation. All populations were grown in a

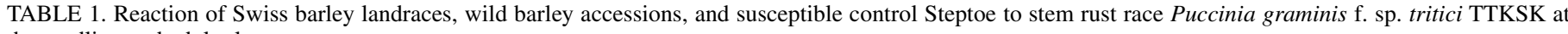
the seedling and adult plant stages

\begin{tabular}{|c|c|c|c|c|c|c|c|}
\hline \multirow[b]{2}{*}{ Accession $^{\mathrm{a}}$} & \multirow[b]{2}{*}{ Origin } & \multirow[b]{2}{*}{ Location } & \multicolumn{2}{|c|}{ Seedling reaction $^{\mathrm{b}}$} & \multicolumn{3}{|c|}{ Sev.\%/IR ${ }^{\mathrm{c}}$} \\
\hline & & & IT mode & IT range & Kenya 2008 & Kenya 2009 & Kenya 2010 \\
\hline Hv501 & Switzerland & Near Bonaduz & $0 ; 1$ & $0 ;$ to $0 ; 1$ & $2 \mathrm{MR}$ & $\ldots$ & $0 \mathrm{R}$ \\
\hline Hv545 & Switzerland & Near Disentis & $0 ; 1$ & $0 ;$ to $0 ; 1$ & $5 \mathrm{MS}$ & $\ldots$ & $0.5 \mathrm{R} / 5 \mathrm{MS}$ \\
\hline Hv602 & Switzerland & Unknown & 0 & $0 ;$ to 10 & $1 \mathrm{R}$ & $\ldots$ & $0 \mathrm{R}$ \\
\hline Hv612 & Switzerland & Near Laret & 0 & $0 ;$ to $0 ; 1$ & $20 \mathrm{MS}-\mathrm{MR}$ & $\ldots$ & $0 \mathrm{R}$ \\
\hline WBDC213 & Uzbekistan & Samarkand & 0 & $0 ;$ to $0 ; 1$ & $\ldots$ & $10 \mathrm{MR} / 20 \mathrm{MS}-\mathrm{S}$ & $\ldots$ \\
\hline WBDC 345 & Uzbekistan & Kashkadarya & $0 ; 1$ & $0 ;$ to 210 & $\ldots$ & Trace MS/Trace R & $\ldots$ \\
\hline Steptoe & United States & Washington & $3^{+}$ & $3^{-2}$ to $3^{+}$ & $40 \mathrm{~S}$ & $\ldots$ & $20 \mathrm{~S}-\mathrm{MS}$ \\
\hline
\end{tabular}

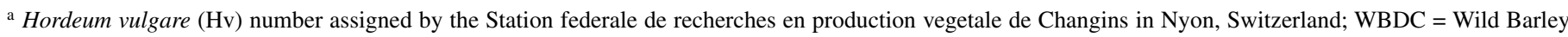
(H. vulgare subsp. spontaneum) Diversity Collection accession described by Steffenson et al. (46).

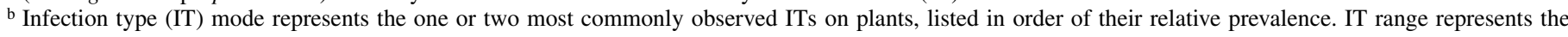
lowest and highest ITs observed on plants. Plants were evaluated for their ITs based on the 0-to-4 scale originally developed for wheat (41) and modified for barley (45). ITs 0,$0 ;, 1,2$, and $23^{-}$were considered indicative of host resistance, whereas types $3^{-}, 3$, and $3^{+}$were considered indicative of susceptibility.

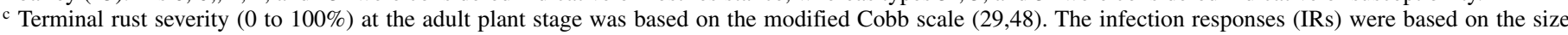
and type of uredinia observed, where $\mathrm{R}=$ resistant; $\mathrm{MR}=$ moderately resistant; $\mathrm{MS}=$ moderately susceptible, and $\mathrm{S}=$ susceptible $(21,37)$. Severity readings of "Trace" denote very low rust infection $(<0.5 \%)$ in the field. The slash symbol $(/)$ indicates the variation in stem rust severity at different times of disease rating during the growing season; ... indicates not tested. 
greenhouse at 19 to $22^{\circ} \mathrm{C}$ with a 14- to 16 -h photoperiod supplemented by $400-\mathrm{W}$ high-pressure sodium lamps emitting a minimum of $300 \mu \mathrm{mol}$ photons $\mathrm{m}^{-2} \mathrm{~s}^{-1}$. When the plants began to emerge from the soil, they were brought into the BSL-3 facility for the remainder of the experiment. Stocks of rust isolate 04KEN156/04 of race TTKSK were prepared and utilized for inoculation following the protocols described by Steffenson et al. (42), with minor modifications. A rust spore suspension (14 mg of urediniospores per $0.7 \mathrm{ml}$ of oil) was applied to 8- to 9-day-old plants with fully expanded primary leaves at a rate of $\approx 0.09$ $\mathrm{mg} /$ plant with an atomizer pressured at 25 to $30 \mathrm{kPa}$ (49). After inoculation, plants were placed in chambers misted with ultrasonic humidifiers, initially for 30 to $40 \mathrm{~min}$ of continuous misting and thereafter for 4 to 8 min every hour for 16 to $18 \mathrm{~h}$ in the dark. After the wetness period, light was provided by $400-\mathrm{W}$ sodium vapor lamps (150 to $250 \mu \mathrm{mol}$ photon $\mathrm{m}^{-2} \mathrm{~s}^{-1}$ ), and the mist chamber doors were slightly opened to dissipate the heat. At this time, the humidifiers were set to run for 4 to $8 \mathrm{~min}$ of misting every $15 \mathrm{~min}$ for the next $2 \mathrm{~h}$. After an additional $2 \mathrm{~h}$, the misters were turned off and the chamber doors were opened halfway to facilitate slow drying of the plant surfaces under continuous light for the next 3 to $4 \mathrm{~h}$. Finally, when the leaf surfaces were completely dry, plants were returned to the greenhouse under the conditions previously described. The parental accessions also were evaluated in limited field trials at the Kenya Agricultural Research Institute in Njoro, Kenya according to the methods described by Zhou et al. (55).

Rust infection phenotyping. At 12 to 14 days after inoculation, stem rust infection types (ITs) were assessed on the first leaves of plants based on the 0-to-4 scale originally developed for wheat by Stakman et al. (41) and modified for barley (45). The IT scale used for barley is based primarily on uredinial size, as described by Miller and Lambert (23). Plants with ITs ranging from 0 to $23^{-}$were classified as resistant and those from $3^{-} 2$ to $3^{+}$ as susceptible. Individual $\mathrm{F}_{3}$ families were grouped into three classes of homozygous resistant (HR), segregating (SEG), or homozygous susceptible (HS) based on the reactions of individual plants.

Statistical test. Pearson's $\chi^{2}$ test was used to evaluate independence of segregation for genetic ratios in the $\mathrm{F}_{3}$ generation. The $\chi^{2}$ statistic and associated $P$ values were calculated using the chisq.test function in Microsoft Excel.

Sample preparation for bulked segregant analysis. HR and $\mathrm{HS} \mathrm{F}_{3}$ families were used for bulked segregant analysis (BSA), an efficient method for tagging and mapping disease $R$ genes $(13,22,34)$. One arbitrarily selected plant from each HR and HS family was grown in the greenhouse and the leaf tissue harvested for DNA extraction. Leaf tissue from plants representing eight $\mathrm{F}_{3}$ families was bulked to create sets of HR and HS bulks for BSA. Three independent sets of both the HR and HS bulks were used in each population. For the Steptoe/Hv602 population, only $20 \mathrm{HR}$ families were used to create the HR bulks because of the limited number of such families identified. Additionally, five seeds each of the resistant parents and Steptoe also were grown and leaf tissue was harvested 2 weeks after sowing for DNA extraction. Samples were freeze-dried using a general-purpose freeze dryer (Model 24DX48; Virtis Company, Gardiner, NY) according to the specifications of the manufacturer.

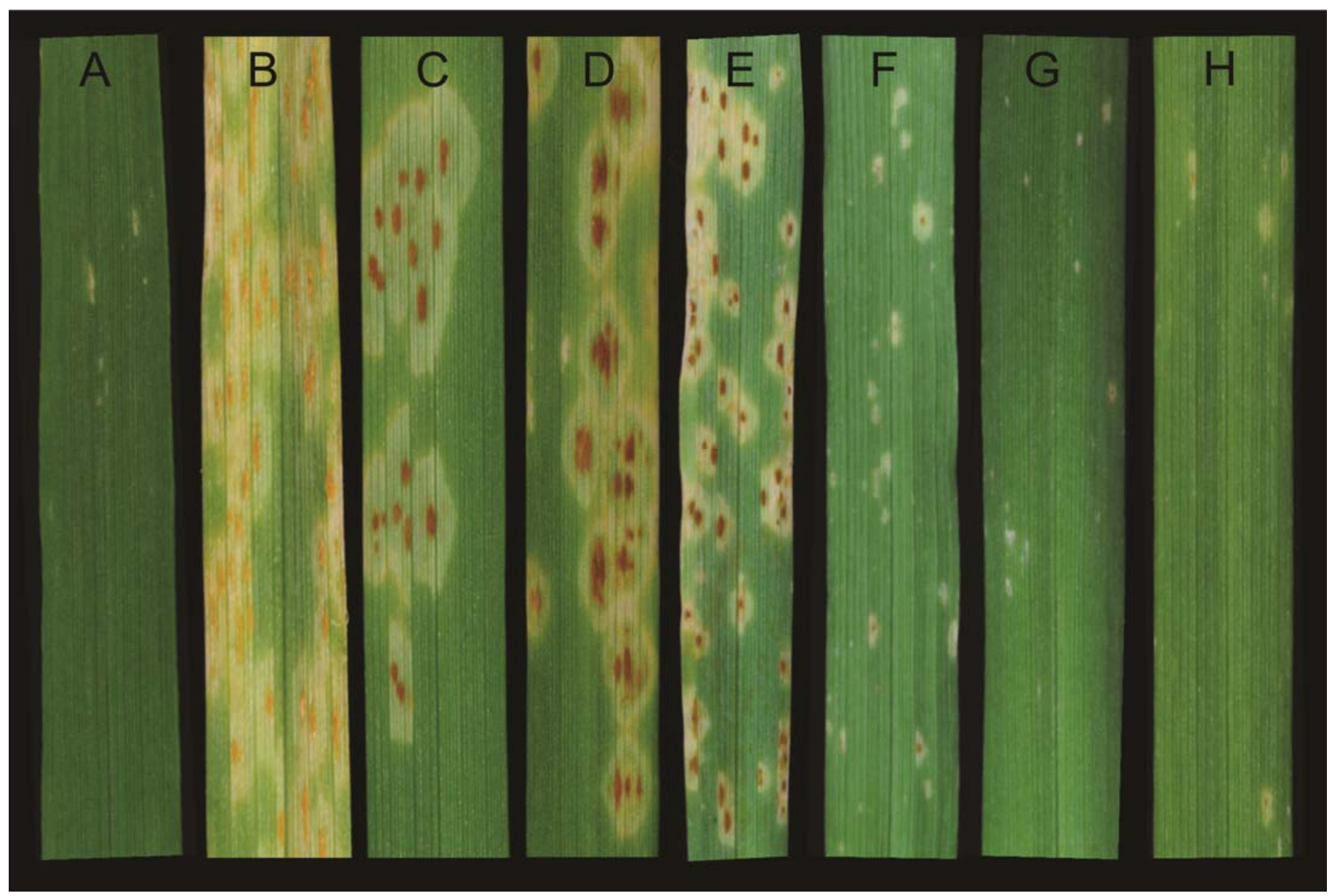

Fig. 1. Disease phenotypes of barley landraces in response to wheat stem rust race TTKSK. A, Highly resistant reaction of Hv545; B, susceptible reaction of $F_{1}$ plant from the Steptoe/Hv545 cross; C, susceptible reaction of Steptoe parent; D, susceptible plant from a homozygous susceptible $\mathrm{F}_{3}$ family of the Steptoe/Hv612 cross; E, moderately susceptible plant from a segregating $\mathrm{F}_{3}$ family of the Steptoe/Hv612 cross; $\mathbf{F}$, resistant plant from a segregating $\mathrm{F}_{3}$ family of the Steptoe/Hv612 cross; $\mathbf{G}$, resistant plant from a homozygous resistant $\mathrm{F}_{3}$ family of the Steptoe/Hv612 cross; and $\mathbf{H}$, highly resistant reaction of Hv612. 
DNA extraction and genotyping. The freeze-dried tissue was used for total genomic DNA extraction using the DNeasy Plant Mini Kit (Qiagen, Valencia, CA) according to the manufacturer's instructions. DNA sample quality was checked by separating and visualizing on a $1 \%$ agarose gel. The amount of DNA in each sample was quantified by measuring absorbance at $260 \mathrm{~nm}$ with a spectrophotometer (Labomed, Inc., Culver City, CA). The DNA concentration of each sample was then normalized to $200 \mathrm{ng} / \mu \mathrm{l}$, and $5 \mu \mathrm{l}$ of each normalized sample was submitted for genotyping with 1,536 single-nucleotide polymorphism (SNP) markers of the Barley Oligonucleotide Pooled Assay 1 (BOPA1) $(5,38)$. The 1,536 SNP markers were tested on the resistant parents, Steptoe, and the three independent HR and HS bulks per population using Illumina Bead Array Technology with the GoldenGate assay $(7,8)$. The BOPA1 SNP markers were previously mapped onto the integrated molecular genetic linkage map of barley $(5,26)$.

Genotype data analysis. Data generated by the GoldenGate assay were visualized and analyzed with the Genotyping Module of the GenomeStudio data analysis software (GSGT version 1.8.4; Illumina, San Diego, CA). SNPs between the respective resistant parents and Steptoe were identified. All of the SNP call data were manually checked, and positive hits for BSA were noted when alleles of at least two of the resistant or susceptible bulks clustered close with alleles of the resistant parent or Steptoe, respectively, in the GenCall output.

Allelism tests. To determine the allelic relationships among stem rust $R$ genes in the different resistant accessions and line Q21861, a half diallel was attempted. Successful crosses were increased to the $F_{2}$ generation. $F_{2}$ seed were sown and plants were inoculated with race TTKSK according to the protocol described above.

Resistance spectrum of parents to other stem rust races. To further characterize the resistance spectrum of TTKSK-resistant accessions and also help resolve whether they may carry the rpg4/Rpg5 $R$ gene complex, three additional races or isolates of the stem rust pathogen were used. Race QCCJ was used because rpg4 (and other genes in concert) (52) is specifically effective against it at low incubation temperatures (18 to $20^{\circ} \mathrm{C}$ ) (17). Because rpg4 is temperature sensitive, assays also were made with race QCCJ at 27 to $28^{\circ} \mathrm{C}$, where the gene is rendered completely ineffective (17). To assay for the presence of the closely linked gene Rpg5, isolate $92-\mathrm{MN}-90$ of $P$. graminis f. sp. secalis, was used. In previous studies, Rpg5 was found to confer a clear low reaction type to this pathogen isolate $(42,50)$. Finally, race HKHJ of $P$. graminis f. sp. tritici was used because it is capable of identifying $R p g l$ in the presence of other $R$ genes (49). Two replications of the parental accessions and control lines were evaluated in experiments that were repeated at least twice in time against each race or isolate. The conditions for plant growth and procedures for inoculation and IT assessment were made according to the methods described previously. The only exception was for the inoculation with race $\mathrm{HKHJ}$, where a concentration of $35 \mathrm{mg}$ of urediniospores per $0.7 \mathrm{ml}$ of oil was used due to a lower than normal germination rate.

Molecular characterization of the rpg4/Rpg5 region. Genotyping for the presence or absence of rpg4-mediated resistance was determined using polymerase chain reaction (PCR) sequence tag site (STS) markers specific to the Rpg5 gene. Two pairs of PCR primers were designed to specifically amplify functional or nonfunctional Rpg5 alleles based on the presence of the serine threonine protein kinase domain (STPK; Rpg5+) or the protein phosphatase 2C domain (PP2C; rpg5-). The sequences of STS markers were designed based on the allele sequence data generated for the three genes at the rpg4/Rpg 5 locus from multiple resistant and susceptible accessions $(2,4,52)$. For each barley line, two separate PCRs were performed using LRK-F1/LRK-R1 and RpgQ-F6/PP2C-R2 primer combinations. The 20- $\mu$ l PCRs consisted of $\approx 100 \mathrm{ng}$ of $\mathrm{gDNA}, 20 \mathrm{pmol}$ of each forward and reverse primers, 1× REDTaq PCR Reaction Buffer (Sigma-Aldrich, St. Louis, MO), $1 \mathrm{U}$ of REDTaq DNA polymerase, and $0.2 \mathrm{mM}$ dNTPs. Amplification was performed in a Mastercycler pro thermocycler (Eppendorf, Hauppauge, NY) using the following parameters: $95^{\circ} \mathrm{C}$ for $4 \mathrm{~min} ; 35$ cycles of $95^{\circ} \mathrm{C}$ for $30 \mathrm{~s}, 62^{\circ} \mathrm{C}$ for $1 \mathrm{~min}$, and $72^{\circ} \mathrm{C}$ for $1 \mathrm{~min}$; followed by $72^{\circ} \mathrm{C}$ for $5 \mathrm{~min}$. Primer sequences for the STS markers are given in Supplemental Table 1 along with the expected size of the PCR products. The Rpg5 gene has three main domains (Supplemental Figure 1) (4). The Rpg5 STS1 marker targets the leucine-rich repeat (LRR) to the STPK region and is specific to the majority of resistant lines (e.g., line Q21861 as a reference genotype). The PP2C STS1 marker amplifies the LRR to the PP2C region and is specific to susceptible lines (e.g., Steptoe). Lines that gave an Rpg5+ result with the Rpg5 STS1 marker were further analyzed for an infrequent allele that gives false-positive results due to the presence of an intact protein kinase domain but a nonfunctional rpg5 allele that contains a single $\mathrm{C}$ insertion causing a frame shift mutation and a predicted truncated nonfunctional RPG5 protein $(2,4)$. To test for this rare nonfunctional allele, a sequence was generated across the region by directly sequencing the amplicon produced using the Rpg5-F1 and Rpg5-R1 primer combination (2). The PCR conditions were the same as described above. The PCRs were purified with cycle pure spin columns (Omega Bio-Tek, Norcross, GA) and sequenced with the Rpg5-R1 primer. Sequencing was performed by GenScript on an ABI 3730xl (Applied Biosystems, Carlsbad, CA).

\section{RESULTS}

Genetics of resistance to race TTKSK of $P$. graminis $\mathbf{f}$. sp. tritici. The landrace (Hv501, Hv545, Hv602, and Hv612) and wild barley (WBDC213 and WBDC345) accessions exhibited highly resistant ITs (modes of 0 ; to $0 ; 1$ ) in response to race TTKSK at the seedling stage (Table 1). In contrast, Steptoe was susceptible, exhibiting an IT mode of $3^{+}$. The resistant accessions also showed much lower rust severities and infection responses than Steptoe in the limited Kenyan field trials where they were included (Table 1). In total, 110 to $187 \mathrm{~F}_{3}$ families from crosses between the resistant barley accessions and Steptoe were evaluated for stem rust reaction in this study (Table 2). Resistant $\mathrm{F}_{3}$ plants exhibited ITs ranging from 0 ; to 12 (rarely 210; or $23^{-}$) and could be easily differentiated from susceptible plants giving ITs of $3^{-2}$ to $3^{+}$(Fig. 1). Thus, individual families of all populations could be confidently grouped into HR, SEG, or HS categories. Segregation data for $\mathrm{F}_{3}$ families of five populations fit a 1:2:1 ratio for HR/SEG/HS ( $\chi^{2}$ of 2.27 to 5.87 with $P$ values of 0.321 to 0.053 , respectively) (Table 2 ). These data indicate that a single gene confers TTKSK resistance in Hv501, Hv545, Hv612, WBDC213, and WBDC345. Segregation data for $F_{3}$ families in the Steptoe/Hv602 population did not fit a 1:2:1 ratio $\left(\chi^{2}=11.95\right.$ and $P=0.003$ ), indicating that more than one TTKSK $R$ gene in Hv602 confers resistance to TTKSK.

To determine whether resistance was dominant or recessive, several different aspects of the segregating populations were investigated. First, a limited number of $F_{1}$ plants were phenotyped. The IT mode of $\mathrm{F}_{1}$ plants from the Steptoe/Hv545 population was similar to that of the susceptible parent Steptoe $\left(3^{-} 2\right.$ versus $\left.33^{+}\right)$ (Fig. 1A to C), suggesting a recessive or at least a partially recessive gene. Unfortunately, no other $F_{1}$ seed were available from the other crosses. Second, the composition of individual plant reactions within each segregating $\mathrm{F}_{3}$ family was tallied to assess possible gene action (20). At least half of the segregating families evaluated in each population (except WBDC213/Steptoe and WBDC345/Steptoe) fit a single gene ratio (20). Some of the segregating $\mathrm{F}_{3}$ families in the six populations did not follow a clear Mendelian ratio for an expected single recessive gene as found for the Steptoe/Hv545 $F_{1}$ plant. For the Steptoe/Hv501, 
Steptoe/Hv602, and WBDC345/Steptoe populations, 56\% (27/48), 57\% (27/47), and 48\% (29/60) of the segregating $\mathrm{F}_{3}$ families, respectively, fit a 1:3 ratio for resistant/susceptible plants, suggesting recessive gene action in the respective resistant parents (20). Unexpectedly, however, 23\% (11/48), 32\% (15/47), and $22 \%(13 / 60)$ of the segregating $\mathrm{F}_{3}$ families of these three respective populations showed dominant gene action (i.e., 3:1 ratio of resistant/susceptible plants) (20). Only one segregating $F_{3}$ family among the Steptoe/Hv545, Steptoe/Hv612, and WBDC213/ Steptoe populations followed a recessive gene action ratio of 1:3 (20). The corresponding number of segregating $F_{3}$ families following a 3:1 ratio for resistant/susceptible plants for these populations was 54\% (13/24), 50\% (15/30), and 45\% (22/49), respectively (20). For the Steptoe/Hv545 population, the dominant gene action discerned from the plants within the segregating families contradicts the putative partially recessive $R$ gene action in Hv545 deduced from the IT of the single Steptoe/Hv545 $\mathrm{F}_{1}$ plant (see below).

Genotyping of parents and bulks, and BSA. In order to determine the chromosomal location of the $R$ genes, genetic analysis was conducted using BSA. In total, 525, 552, 564, 588, 568, and 561 SNPs were identified between the resistant parents
Hv501, Hv545, Hv602, Hv612, WBDC213, and WBDC345, respectively, and susceptible parent Steptoe after screening with 1,536 BOPA1 SNPs. Markers with possible linkage to the resistance locus were determined after establishing two broad criteria. First, SNPs differentiating at least two of the HR bulks (plus the resistant parent) and two of the HS bulks (plus Steptoe) were considered to be putatively linked SNP markers to the resistance loci in the TTKSK-resistant barley accessions (Table 3). Accordingly, alleles of $18 \mathrm{SNPs}$ in total (1 in Steptoe/Hv501, 3 in Steptoe/Hv545, 4 in Steptoe/Hv602, and 5 each in Steptoe/Hv612 and WBDC345/Steptoe $\mathrm{F}_{3}$ families) differed between two or more of the HR and HS bulks. Of these, one SNP each in all of the three resistant and susceptible bulks of Steptoe/Hv545 and Steptoe/Hv612 and two SNPs in all of the three resistant and susceptible bulks of WBDC345/Steptoe clustered together with the respective resistant parent (Table 3, SNPs in bold). Second, in cases where alleles of all the HR bulks were similar to the allele clusters of the resistant parent and alleles of the susceptible bulks had a different cluster from the susceptible parent, the SNP was considered to be a putative "candidate" marker linked to the identified $R$ gene in the populations (Table 3, SNPs in italic). This second criterion was considered because a mutation or some other

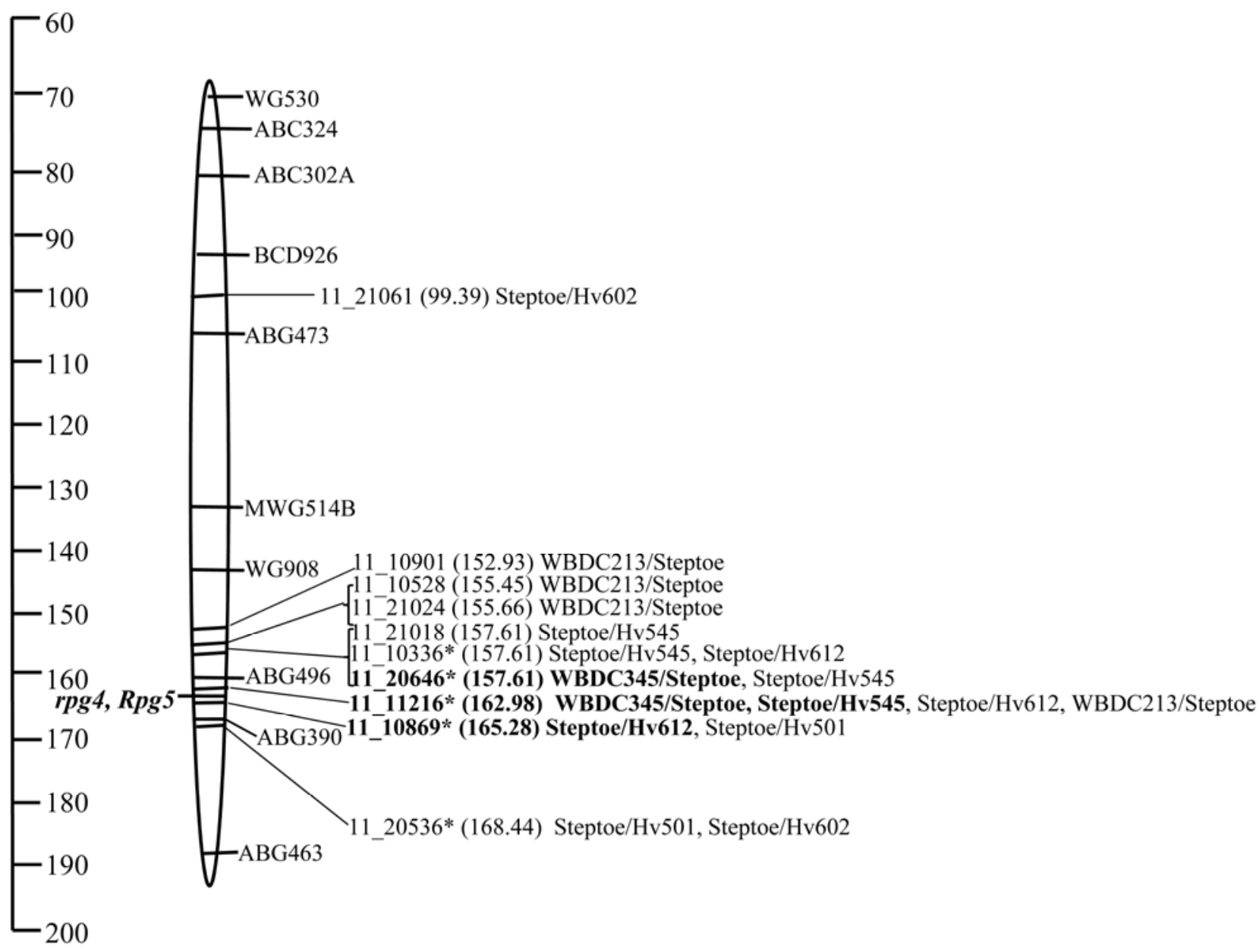

Fig. 2. Consensus genetic map of the long arm of chromosome $5 \mathrm{H}$ of barley. The consensus map was constructed from the Steptoe/Morex (SM) doubled haploid line population (18) and modified from a presentation by R. Brueggeman (unpublished data). Single-nucleotide polymorphism (SNP) markers detected in the subtelomeric region of the long arm of chromosome $5 \mathrm{H}$ through bulked segregant analysis are indicated with the thinner and longer line. SNP marker names begin with numbers according to the BOPA_C nomenclature used by Close et al. (5) followed by the name of the cross in which they were detected. Cumulative centimorgan (cM) distances are in parenthesis next to the marker name as given by Muñoz-Amatriaín et al. (26). The stem rust resistance gene complex rpg4/Rpg5, given in bold italics on the left-hand side of the subtelomeric region of the hypothetical chromosome arm, was previously mapped to this region (3,42). The cM position of the rpg4/Rpg5 locus and the linked restriction fragment length polymorphism marker ABG390 is approximate based on the map position of the latter in recent barley consensus maps (11). SNP markers that were positive in each of the three resistant and susceptible bulks are indicated in bold. SNPs detected in more than one population are followed by an asterisk. The line scale on the left side of the figure gives approximate map distances in Kosambi cM at 10 -cM intervals. 
genetic change might contribute to the shift of the allele cluster of the susceptible bulks away from the allele cluster of the susceptible parent. Based on this criterion, alleles of 12 SNP markers in total (2 each in Steptoe/Hv501 and Steptoe/Hv545, 3 in Steptoe/ Hv602, and 5 in WBDC213/Steptoe $F_{3}$ families) clustered with the resistant parent in all three resistant bulks (Table 3, SNPs in italic).

Most of the 1,536 SNP markers used in this study were previously mapped onto the integrated consensus map of barley $(5,18,26)$. Almost all SNPs that had their alleles clustered with alleles of the respective parent in all three resistant and susceptible bulks were located within a 10-centimorgan $(\mathrm{cM})$ region of the long arm of chromosome 5H between SNP markers 11_10528 and 11_10869 (Table 3; Figs. 2 and 3). Likewise, most SNPs that had their alleles clustered with the resistant parent in all three resistant bulks (positive SNPs) - regardless of their pattern in the HS bulks of all six populations-were located within the same region of chromosome 5HL. Other SNPs where two of the resistant bulks clustered with the resistant parent or where two or more of the susceptible bulks clustered with the susceptible parent also were located in the same interval of chromosome $5 \mathrm{H}$ in all populations (Table 3; Figs. 2 and 3). This result suggests that all six barley accessions contain an $R$ gene mapping to the same region of chromosome 5H. The rpg4/Rpg5 complex locus in Q21861 also maps to this same region of chromosome 5HL (42). One exception to note is that, in the Steptoe/Hv602 population, an SNP (marker 11_21061) that maps at $99.39 \mathrm{cM}$ on the same arm of chromosome $5 \mathrm{H}$ had all three resistant bulks clustered with the resistant parent (Table 3; Fig. 2). This region is interesting because Zhou et al. (55) identified a novel adult plant resistance locus against race TTKSK in the 69.3- to 103.9-cM interval of 5HL. An SNP marker (11_21472) mapping to the long arm of chromosome $3 \mathrm{H}$ at $66.62 \mathrm{cM}$ had three of the resistant bulks clustered with the resistant parent in the Steptoe/Hv612 population.

Allelism tests. Crosses for the half diallel among the resistance sources and to Q21861 were only obtained for 6 of the 21 possible combinations: Hv545/Hv602 (300 progeny), Hv545/Hv612 (140 progeny), Hv602/Hv612 (280 progeny), Q21861/Hv501 (680 progeny), Q21861/Hv545 (500 progeny), and Q21861/ Hv612 (760 progeny) (Supplemental Table 2). Successful crosses were not obtained for the other combinations, due mostly to flowering time differences and poor pollen production. All progeny from crosses Hv545/Hv602, Hv545/Hv612, and Hv602/Hv612 exhibited resistant ITs to race TTKSK, indicating that the same

\section{Genotype calls for 11_1053 in Steptoe/Hv612}

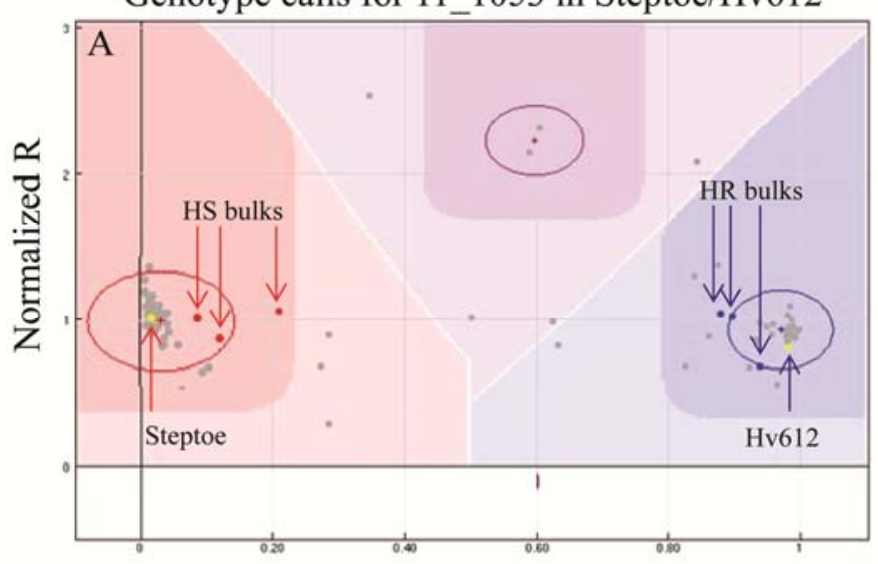

Genotype calls for 11_0655 in WBDC345/Steptoe

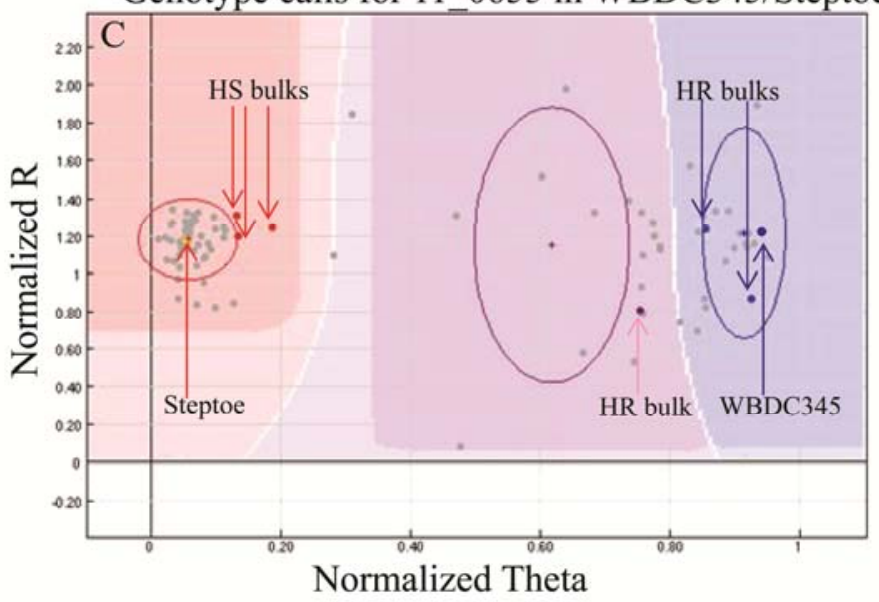

\section{Genotype calls for 110959 in Steptoe/545}

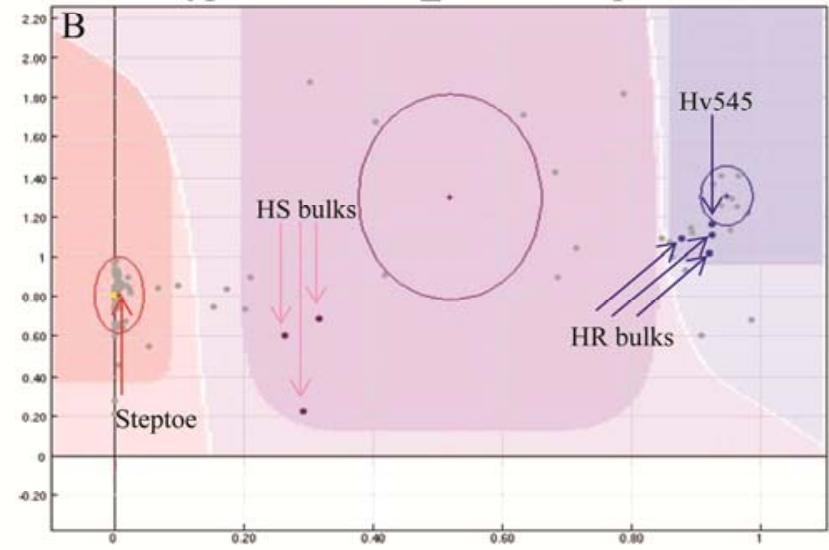

Genotype calls for 11_1053 in Steptoe/Hv545

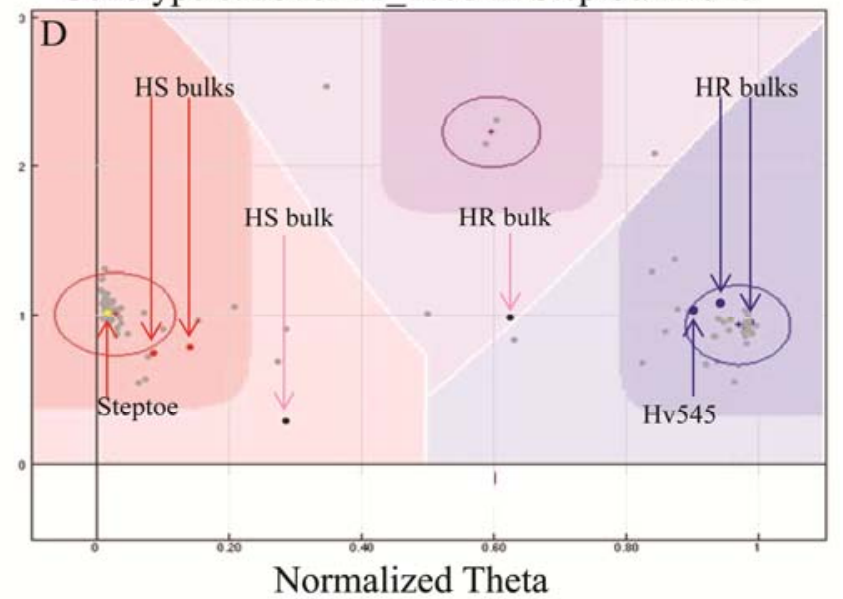

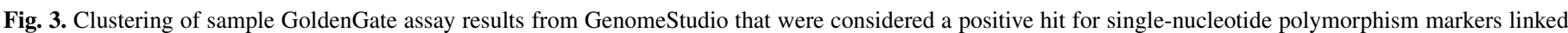

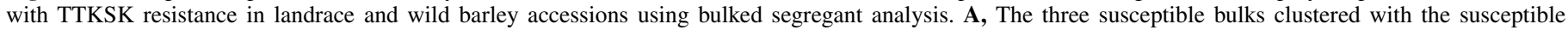

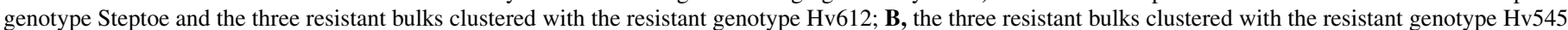

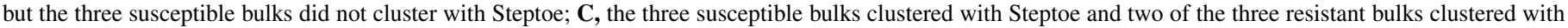

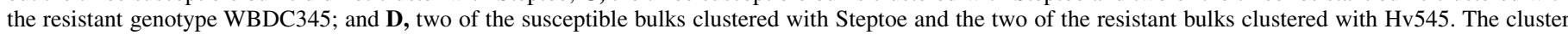

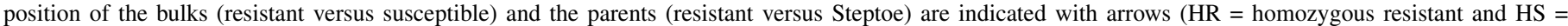

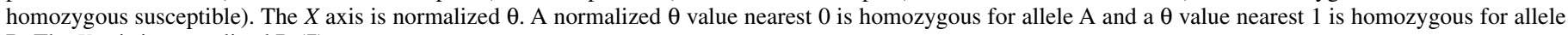
B. The $Y$ axis is normalized $\mathrm{R}$ (7). 
allele imparts resistance in the three Swiss landraces. Similar results were obtained in populations involving landraces Hv501, Hv545, and Hv612 crossed to Q21861, indicating that the $R$ genes were allelic to the rpg4/Rpg 5 complex. One $\mathrm{F}_{2}$ plant derived from Q21861/Hv501 and three $F_{2}$ plants derived from Q21861/Hv612 showed an intermediate IT but these were retested and later confirmed to be resistant to race TTKSK. Attempts at other crosses for the half diallel were not successful; however, some deductions may be made based on the current results. Although Hv602 was not successfully crossed to Q21861, it likely carries an $R$ gene allelic to the rpg4/Rpg 5 complex based on the allelism of Hv602 to Hv612 and Hv612 to Q21861.

Resistance spectrum of parents to other stem rust races. Landrace and wild barley accessions were inoculated with three additional races or isolates of $P$. graminis to help resolve whether they contain the same $R$ gene complex of rpg4/Rpg 5 and also to profile their resistance spectrum. Steptoe, the susceptible control, gave high ITs to all races tested (Table 4). The landrace and wild barley accessions reacted the same as the resistant controls of Q21861 (with rpg4/Rpg5 and Rpg1) and QSM20 (with rpg4/ $R p g 5$ ) to race QCCJ at low-temperature (ITs of 0 ; to $0 ; 1$ ) and high-temperature $\left(3^{-} 2\right)$ incubation. The TTKSK-resistant accessions also were evaluated against $P$. graminis $\mathrm{f}$. sp. secalis isolate 92-MN-90 to determine whether they carry Rpg5. All accessions exhibited low ITs $(0 ;$ to $0 ; 1)$, similar to those of Q21861 and QSM20, suggesting that they also carry Rpg5. Finally, the six TTKSK-resistant accessions were evaluated to race HKHJ to assess whether they might carry Rpg1. Accessions Hv501, Hv612,

TABLE 2. Segregation for resistance in $\mathrm{F}_{3}$ families from crosses of landrace and wild barley accessions with Steptoe to race TTKSK of Puccinia graminis $\mathrm{f}$. sp. tritici at the seedling stage

\begin{tabular}{|c|c|c|c|c|c|c|}
\hline \multirow[b]{2}{*}{ Cross } & \multicolumn{3}{|c|}{ Number of $\mathrm{F}_{3}$ families ${ }^{\mathrm{a}}$} & \multirow[b]{2}{*}{ Expected ratio } & \multirow[b]{2}{*}{$\chi^{2}$ value $(2 \mathrm{df})$} & \multirow[b]{2}{*}{ Probability $\left(>\chi^{2}\right)^{\mathrm{b}}$} \\
\hline & HR & SEG & HS & & & \\
\hline Steptoe/Hv501 & 32 & 48 & 40 & $1: 2: 1$ & 5.87 & $0.053 \mathrm{~ns}$ \\
\hline Steptoe/Hv545 & 48 & 98 & 35 & $1: 2: 1$ & 3.11 & $0.211 \mathrm{~ns}$ \\
\hline Steptoe/Hv602 & 20 & 47 & 43 & $1: 2: 1$ & 11.95 & $0.003 * *$ \\
\hline Steptoe/Hv612 & 39 & 88 & 60 & $1: 2: 1$ & 5.36 & $0.068 \mathrm{~ns}$ \\
\hline WBDC213/Steptoe & 30 & 52 & 36 & $1: 2: 1$ & 2.27 & $0.321 \mathrm{~ns}$ \\
\hline WBDC345/Steptoe & 32 & 76 & 52 & $1: 2: 1$ & 5.40 & $0.067 \mathrm{~ns}$ \\
\hline
\end{tabular}

${ }^{a}$ Homozygous resistant (HR), segregating (SEG), or homozygous susceptible (HS).

b Symbols: $\mathrm{ns}=$ not significant at 0.05 and $* *=$ significant at 0.01 .

TABLE 3. Chromosomal position of markers associated with resistance against stem rust race TTKSK in landrace and wild barley accessions as determined by bulked segregant analysis

\begin{tabular}{|c|c|c|c|c|c|}
\hline Chromosome $^{\mathrm{a}}$ & Position $(\mathrm{cM})^{\mathrm{b}}$ & SNP designation $^{\mathrm{c}}$ & Mapping population $^{\mathrm{d}}$ & $\mathrm{HR}^{\mathrm{e}}$ & $\mathrm{HS}^{\mathrm{f}}$ \\
\hline $3 \mathrm{H} \mathrm{L}$ & 66.62 & 11_21472 & Steptoe/Hv612 & 2 & 3 \\
\hline \multirow[t]{23}{*}{$5 \mathrm{H} \mathrm{L}$} & 51.51 & 11_20501 & Steptoe/Hv602 & 1 & 3 \\
\hline & 99.39 & 11_21061 & Steptoe/Hv602 & 3 & 1 \\
\hline & 155.45 & $11 \_10528$ & WBDC213/Steptoe & 3 & 1 \\
\hline & 155.66 & 11_21024 & WBDC213/Steptoe & 3 & 0 \\
\hline & 157.61 & 11_10336 & Steptoe/Hv545 & 3 & 2 \\
\hline & 157.61 & 11_10336 & Steptoe/Hv602 & 2 & 2 \\
\hline & 157.61 & 11_20646 & Steptoe/Hv545 & 3 & 1 \\
\hline & 157.61 & 11_20646 & Steptoe/Hv602 & 2 & 2 \\
\hline & 157.61 & 11_20646 & Steptoe/Hv612 & 2 & 2 \\
\hline & 157.61 & 11_20646 & WBDC345/Steptoe & 3 & 3 \\
\hline & 157.61 & 11_21018 & Steptoe/Hv545 & 3 & 0 \\
\hline & 158.28 & $11 \_11464$ & WBDC345/Steptoe & 2 & 3 \\
\hline & 162.98 & 11_11216 & Steptoe/Hv545 & 3 & 3 \\
\hline & 163.72 & 11_20546 & Steptoe/Hv612 & 2 & 3 \\
\hline & 163.72 & 11_20686 & WBDC345/Steptoe & 2 & 3 \\
\hline & 164.15 & 11_20644 & Steptoe/Hv602 & 3 & 1 \\
\hline & 164.15 & 11_20644 & WBDC213/Steptoe & 3 & 1 \\
\hline & 165.28 & 11_10869 & Steptoe/Hv501 & 3 & 1 \\
\hline & 165.28 & 11_10869 & Steptoe/Hv545 & 2 & 2 \\
\hline & 165.28 & 11_10869 & Steptoe/Hv602 & 2 & 2 \\
\hline & 165.28 & 11_10869 & Steptoe/Hv612 & 3 & 3 \\
\hline & 168.44 & 11_20536 & Steptoe/Hv501 & 3 & 0 \\
\hline & 168.44 & 11_20536 & Steptoe/Hv602 & 3 & 0 \\
\hline
\end{tabular}

\footnotetext{
a Chromosome and arm.
}

${ }^{\mathrm{b}}$ Single-nucleotide polymorphism (SNP) marker position along chromosome, according to Muñoz-Amatriaín et al. (26).

c SNP marker BOPA_C nomenclature according to Close et al. (5). SNP markers that were positive in each of the three resistant and susceptible bulks are indicated in bold; SNP markers that were positive in each of the three resistant bulks and in none or one of the susceptible bulks were considered as putative "candidate" SNPs and are indicated in italics.

${ }^{\mathrm{d}}$ Mapping population in which associations were identified.

e Number of homozygous resistant (HR) bulks (out of three) which have alleles identical to the respective resistant parent.

f Number of homozygous susceptible (HS) bulks (out of three) which have alleles identical to the respective susceptible parent. 
WBDC213, and WBDC345 exhibited high ITs (3-2 to $3^{-} 3$ ) to race HKHJ, suggesting that they lack Rpgl. Accessions Hv545 and Hv602 gave intermediate ITs of 210; and 213-, respectively. These two accessions exhibited similar ITs in repeated evaluations and, therefore, possess a resistance spectrum that is different from the other studied accessions. Q21861 and QSM20 gave low $(0 ;)$ and high $\left(33^{+}\right)$ITs to race HKHJ, confirming the presence and absence, respectively, of Rpgl in the accessions.

Molecular characterization of the $\operatorname{Rpg} 5$ region. The parental lines were genotyped at the rpg4/Rpg5 region using STS markers $(4,52)$ (GenBank accession number EU812563) to assay for the presence of Rpg5. All accessions contained the nucleotide binding site (NBS) of the Rpg5 gene (Table 5). Additionally, all resistant parents and Q21861 contained an intact STPK domain at the 3' end of the Rpg5 gene, indicating that the gene is functional in all resistant accessions. Steptoe contained the nonfunctional allele of Rpg 5 because it lacks the STPK domain.

\section{DISCUSSION}

Race TTKSK is a serious threat to wheat and barley production worldwide because of its virulence on multiple $R$ genes of agricultural importance. Steffenson et al. (42) previously reported that the stem rust resistance locus $r p g 4 / R p g 5$ in Q21861 was the only one described in barley that confers resistance against race TTKSK. In an effort to identify additional genes for resistance to race TTKSK, a large and diverse collection of Hordeum germplasm was evaluated at the seedling stage (47). Several Swiss landrace (Hv501, Hv545, Hv602, and Hv612) and wild barley (WBDC213 and WBDC345) accessions were among the most resistant identified to race TTKSK. To fully characterize the genetics of resistance in these accessions, the following studies were conducted: (i) biparental populations were developed to determine the inheritance of resistance and define the chromosomal locations of the resistance loci using BSA, (ii) allelism tests were made to resolve the relationships of genes among some of the resistance sources, (iii) accessions were tested to other stem rust races to characterize the resistance spectrum of the genes and postulate their possible identity, and (iv) specific primers were used for detecting Rpg5, a gene implicated with rpg4 in conferring resistance to race TTKSK.

TABLE 4. Seedling infection types (ITs) of parental lines and controls in response to wheat stem rust races Puccinia graminis f. sp. tritici QCCJ and HKHJ and rye stem rust isolate $P$. graminis f. sp. secalis $92-\mathrm{MN}-90$

\begin{tabular}{|c|c|c|c|c|}
\hline \multirow[b]{3}{*}{ Accession $^{\mathrm{b}}$} & \multicolumn{4}{|c|}{ IT mode ${ }^{a}$} \\
\hline & \multicolumn{2}{|c|}{ QCCJ } & \multirow{2}{*}{$\frac{\mathrm{HKHJ}}{21^{\circ} \mathrm{C}}$} & \multirow{2}{*}{$\frac{92-\mathrm{MN}-90}{21^{\circ} \mathrm{C}}$} \\
\hline & $21^{\circ} \mathrm{C}$ & $28^{\circ} \mathrm{C}$ & & \\
\hline Hv501 & $0 ; 1$ & $3^{-2}$ & $3-2$ & 0 \\
\hline Hv545 & $0 ; 1$ & $3-2$ & 210 & 0 \\
\hline Hv602 & $0 ; 1$ & $3-2$ & $213^{-}$ & $0 ; 1$ \\
\hline Hv612 & $0 ; 1$ & $3-2$ & $3-2$ & 0 \\
\hline WBDC213 & 0 & $3-2$ & $3-3$ & 0 \\
\hline WBDC345 & $0 ; 1$ & $3-2$ & $3-2$ & $0 ; 1$ \\
\hline Q21861 & $0 ; 1$ & $3-2$ & 0 & 0 \\
\hline QSM20 & $0 ; 1$ & $3^{-2}$ & $33^{+}$ & 0 \\
\hline Steptoe & $3-2$ & $33^{+}$ & $3-3$ & $3-2$ \\
\hline
\end{tabular}

a IT mode represents the one or two most commonly observed ITs on plants, listed in order of their relative prevalence, at the incubation temperatures under which plants were grown after stem rust inoculation. Plants were evaluated for their ITs based on the 0-to-4 scale originally developed for wheat (41) and modified for barley (45). ITs 0,$0 ;, 1,2$, and $23^{-}$are considered indicative of host resistance, and types $3^{-}, 3$, and $3^{+}$are indicative of susceptibility.

${ }^{\mathrm{b}}$ Hordeum vulgare) number assigned by the Station federale de recherches en production vegetale de Changins in Nyon, Switzerland; WBDC: Wild Barley (H. vulgare subsp. spontaneum) Diversity Collection accession described by Steffenson et al. (46).
Genetic analysis of the segregating populations clearly indicated that a single gene confers seedling resistance to race TTKSK in accessions Hv501, Hv545, Hv612, WBDC213, and WBDC345. In accession Hv602, more than one gene was involved in conferring seedling resistance (Table 2). Monogenic inheritance for resistance to different races or isolates of the wheat and rye stem rust pathogens have been reported in a number of barley accessions in previous studies $(9,10,14,17,28,39,43,50)$. Steffenson et al. (42) reported that resistance to race TTKSK in Q21861 segregates as a single gene that lies at the rpg4/Rpg5 region. It appears that this same gene complex confers resistance in the accessions characterized in this study. Perhaps this complex locus and some other gene is involved in conferring resistance in Hv602. The population Steffenson et al. (42) evaluated had only 129 progeny and, therefore, segregation of the two closely linked genes was unlikely. The recessive gene rpg4 controls resistance to race QCCJ in Q21861 at low incubation temperatures (18 to $21^{\circ} \mathrm{C}$ ) (17). This gene also was thought to confer resistance to rye stem rust in a partially dominant fashion (50) until Brueggeman et al. (4) identified recombinants exhibiting resistance to $P$. graminis f. sp. secalis isolate $92-\mathrm{MN}-90$ and not race QCCJ in a single large segregating population (Steptoe/Q21861). However, the second tightly linked locus containing the Rme1 (rpg4-modifier element 1) gene identified in the Steptoe/Q21861 population that is required for rpg4-mediated resistance is only polymorphic in this population and not in the other two large populations analyzed (MD2/Q21861 and Harrington/Q21861). These data suggested that the Rpg5 gene conferring resistance to rye stem rust is partially dominant and lies only a few recombination units from $R m e 1$, yet is the polymorphic resistance $(R)$ gene at the locus and the major determinant of rpg4-mediated resistance $(4,52)$.

Efforts to characterize the gene action (recessive versus dominant) of TTKSK resistance in the resistance sources did not yield clear-cut results. The IT mode of a single $F_{1}$ plant from the Steptoe/Hv545 population and the ratio of plant reaction types within 48 to $57 \%$ of segregating $\mathrm{F}_{3}$ families of the Steptoe/Hv501, Steptoe/Hv602, and WBDC345/Steptoe populations were suggestive of a recessive or at least partially recessive-acting $R$ gene. In contrast, the ratio of plant reaction types in other segregating $F_{3}$ families was suggestive of a dominant gene. One explanation for the lack of conclusive results concerning gene action based on segregating $\mathrm{F}_{3}$ families is that multiple genes are likely involved in the phenotype, as recently found by Wang et al. (42), and, therefore, some $\mathrm{F}_{3}$ plants might represent various recombinations of genes at other loci that interact with the rpg4/Rpg 5 complex of genes. The contention of additional genes being involved was supported by the IT data observed in the Steptoe/Hv501 popu-

TABLE 5. Genotyping and sequencing of landrace and wild barley accessions for the wheat stem rust resistance gene $R p g 5$

\begin{tabular}{|c|c|c|c|c|}
\hline Accession & $\operatorname{Rpg} 5^{\mathrm{a}}$ & Kinase $^{b}$ & $5^{\prime}$ end insertion ${ }^{c}$ & Sequence \\
\hline Hv501 & + & + & - & Unknown \\
\hline Hv545 & + & + & - & Unknown \\
\hline Hv602 & + & + & - & + \\
\hline Hv612 & + & + & - & Unknown \\
\hline WBDC 213 & + & + & - & Unknown \\
\hline WBDC 345 & + & + & - & Unknown \\
\hline Q21861 & + & + & - &,$+ \mathrm{D}$ \\
\hline Steptoe & + & - & Unknown &,$- \mathrm{D}$ \\
\hline
\end{tabular}

a Rpg5 nucleotide binding site region was present.

b The C-terminal protein kinase is intact (+ indicates resistant genotype) or replaced by the PP2C gene (-indicates susceptible genotypes).

c The $5^{\prime}$ end of the allele does not contain an insertion that results in a frame shift and truncated Rpg5 protein (-).

${ }^{\mathrm{d}}$ Resistant genotype (+) or susceptible genotype (-) based on the sequenced portions of the allele; $\mathrm{D}$ indicates that the entire allele has been sequenced (52). 
lation, where some resistant families exhibited intermediate ITs instead of the typical 0 ; to $0 ; 1$ types shown by the resistant parent. In addition, some plants in the susceptible families of the Steptoe/ Hv602 population had quite variable ITs, ranging from $3^{-2}$ to $3^{+}$. This suggests again that there might be complementary $R$ genes involved in the populations. In fact, segregation data of the Steptoe/Hv602 population indicated that TTKSK resistance involves more than one gene. Indeed, the recessive nature of $r p g 4$ is determined at the Rpg5 locus by the HvPP2C dominant susceptibility factor (R. Brueggeman, unpublished data). Preliminary expression analysis data suggest that the expression levels of Rpg 5 and the interaction of Rpg 5 with HvPP2C may determine the recessive versus dominant nature of rpg4/Rpg5-mediated resistance, suggesting that other genes segregating in these populations, possibly transcriptional regulators similar to those proposed by Moscou et al. (24), could be influencing the nature of gene action in the resistance sources (R. Brueggeman, unpublished data). Further evaluation of the rpg4/Rpg5 locus and other loci influencing the resistance in the populations reported here may help determine the dominant or recessive nature of rpg4/ Rpg5-mediated resistance.

The rpg4 locus (now the rpg4/Rpg5 complex locus) was mapped to the long arm of barley chromosome $5 \mathrm{H}$ using molecular markers $(3,6)$. Rpg5 was later isolated through positional cloning (4). Recent high-resolution recombinant analysis by Wang et al. (52) indicated that the rpg4/Rpg 5 region spans an $\approx 290$-kbp physical region and contains several candidate genes. Wang et al. (52) have implicated Rpg5, along with other tightly linked genes in the region, in rpg4-mediated resistance against races TTKSK and QCCJ. The multiple genes in the rpg4/Rpg5 region required for resistance to TTKSK and QCCJ often segregate as a single locus because they are very closely linked (i.e., within an $\approx 70-\mathrm{kbp}$ genetic interval). Research is underway to characterize additional informative recombinants in the region to resolve which genes are essential for conferring TTKSK resistance (52). This information will be useful for identifying the genes needed to confer TTKSK resistance in the landrace and wild barley accessions.

After demonstrating a monogenic inheritance pattern for all but one of the resistant accessions, BSA was used to approximate the chromosomal locations of the TTKSK resistance loci. Several SNP markers identified using BSA in the six populations were previously mapped to the subtelomeric region of the long arm of chromosome $5 \mathrm{H}$ in the 158 - to 165 -cM interval between SNP markers 11_10336 and 11_10869 (26). The SNPs identified by BSA lie in a region coincident with $\operatorname{rpg} 4 / \operatorname{Rpg} 5$. A previous but lower-resolution mapping study of the $R$ gene $r p g 4$ in the Q/SM population using restriction fragment length polymorphism (RFLP) markers identified MWG740 and ABG390 as linked markers (3). That study mapped rpg4 $5.7 \mathrm{cM}$ distal from the RFLP marker ABG390. On recent consensus maps, ABG390 lies in the same genomic region with the SNP markers detecting the TTKSK resistance locus in the current study (26) (http://wheat.pw.usda.gov/ GG2/index.shtml). Steffenson et al. (42) mapped the genes conferring TTKSK resistance in Q21861 to the rpg4/Rpg5 complex locus based on the cosegregation of this resistance with the previously mapped rpg4 locus conferring resistance to race QCCJ and also resistance to $P$. graminis $\mathrm{f}$. sp. secalis isolate 92MN-90 (50). Moscou et al. (24) mapped qualitative TTKSK seedling stage resistance in the Q/SM population to $146.78 \mathrm{cM}$ on chromosome $5 \mathrm{H}$ using mRNA transcript abundance with the Barley1 Affymetrix array. Based on the chromosomal position in consensus maps of RFLP markers linked to the rpg4 locus, specifically ABG390, the TTKSK resistance locus detected by BSA analysis in this study lies very near the rpg4/Rpg 5 complex locus. In BSA, SNP markers that were positive in each of the three resistant and susceptible bulks and also detected in more than one population were positioned at a more proximal location on chromosome $5 \mathrm{H}$, closer to the putative location of rpg4/Rpg 5 (Fig. 2, SNPs in bold). Other markers, not positive in all three resistant and susceptible bulks and detected in only one of the populations, were positioned at more distal locations on the chromosome. The other interesting region to note is the 69.3- to 103.9-cM interval of chromosome 5HL, where a novel adult plant TTKSK resistance locus was identified through association mapping in U.S. barley breeding germplasm (55). BSA of the Steptoe/Hv602 population identified a marker (SNP 11_21061) that maps at $99.39 \mathrm{cM}$ on the same arm of chromosome $5 \mathrm{H}$. This region of chromosome 5HL may contain a gene that interacts with the rpg4/Rpg 5 complex locus to impart TTKSK resistance in Hv602.

Steffenson et al. (46) identified DArT markers significantly associated with wheat stem rust (race MCCF) resistance in the rpg4/Rpg5 gene complex region of chromosome $5 \mathrm{H}$ through association mapping in the WBDC. A biparental mapping study with one of the resistant wild barley accessions (WBDC348, also known as 'Damon') identified a single major gene conferring resistance to stem rust races $\mathrm{MCCF}$ and QCCJ in the same bin as rpg4/Rpg5 (1). Research is underway to continue high-resolution recombinant analysis in the rpg4/Rpg5 region to precisely map these resistant loci (52).

To provide additional data regarding the relationships among the $R$ genes identified in the six accessions and also the rpg4/ Rpg5 complex in Q21861, tests of allelism were made. No segregation was observed in crosses between the Swiss landraces (Hv501, Hv545, and Hv612) and Q21861 with the rpg4/Rpg5 complex. This indicates that the genes conferring TTKSK resistance in the landraces are either allelic with those at the rpg4/ Rpg 5 locus or are closely linked to it. Further confirmation of this finding was obtained from the allelism tests among selected Swiss landraces. No segregation was observed in any of these populations, demonstrating that Hv501, Hv545, Hv612, and Hv602 all carry the same allele for resistance to race TTKSK and that it resides at rpg4/Rpg5 locus.

To obtain more data as to whether the resistant accessions contain the same $R$ gene complex of rpg4/Rpg5, additional phenotype evaluations were made with $P$. graminis f. sp. tritici races QCCJ and HKHJ and $P$. graminis $\mathrm{f}$. sp. secalis isolate 92MN-90. These tests were critical because the genes have unique hallmarks: rpg4 is temperature sensitive (17) and Rpg5 specifically confers resistance to rye stem rust without the need for other genes (50). The Swiss landraces and wild barley lines exhibited resistant ITs against race QCCJ at low temperature and susceptible ITs at high temperature, similar to those exhibited by Q21861 with the rpg4/Rpg5 complex $(4,42)$. The resistant accessions also gave low ITs against $P$. graminis f. sp. secalis isolate 92-MN-90, similar to those exhibited by Q21861, suggesting that they also carry Rpg5 (Table 4). These results strongly support our hypothesis that the six resistance sources contain the rpg4/Rpg5 locus. Tests with race HKHJ indicated that Hv501, Hv612, WBDC213, and WBDC345 likely lack Rpg1. This result is in agreement with Rpgl-specific marker analysis that revealed the absence of this gene in the Swiss landraces (B. Steffenson and R. Brueggeman, personal communication). Two accessions (Hv545 and Hv602) exhibited unexpected ITs in response to race HKHJ over multiple evaluations. Known controls with Rpgl gave classical ITs of 0; to 10; when tested with race HKHJ. In contrast, Hv545 and Hv602 exhibited low to intermediate ITs of 210; and $213^{-}$, respectively, to this race. Rpgl-specific marker analysis indicated that these two landraces lack Rpgl (B. Steffenson and R. Brueggeman, personal communication). However, they may carry a partially effective gene against race HKHJ. This result should be verified further, including testing the two accessions with stem rust races under different temperature conditions.

Molecular haplotyping provided another strong piece of evidence concerning the presence of a functional Rpg5 gene in the 
six resistant accessions. Rpg5 encodes a protein with NBS, leucine-rich, and protein kinase domains (4). Molecular characterization of the Rpg5 region with STS markers indicated that all six resistant accessions contain a functional Rpg5 gene (Table 5). A sequenced portion of the allele also revealed that the STPK domain at the C-terminus end of the Rpg5 gene is intact. The STPK domain is a functionally crucial unit of Rpg 5 for conferring resistance. These data demonstrate that TTKSK resistance in landrace and wild barley accessions likely involves Rpg5. By lieu of its close linkage to other genes, the presence of Rpg5 in these sources also strongly suggests the presence of rpg4 and other nearby genes needed for conferring TTKSK resistance. The latest research on stem rust resistance mediated by the rpg4/Rpg 5 region suggests that Rpg5 is the $R$ gene that is responsible for the gene-for-gene interaction determining rpg4-mediated resistance and is the only reliable gene with polymorphism that can be used to determine the presence of rpg4-mediated resistance (2). In the future, any newly discovered barley accessions with TTKSK resistance should be initially screened for the presence of the functional Rpg5 gene to determine whether or not the resistance might be novel. This test will likely serve to detect other genes at the locus because rpg4 and Rpg5 are likely conserved, as revealed by their discovery both in landrace and also wild barley accessions.

In summary, segregation data from $\mathrm{F}_{3}$ families developed from crosses of landrace and wild barley accessions with susceptible Steptoe indicated that a single locus confers resistance to race TTKSK in five of the six populations and that more than one locus governs resistance in Hv602. Molecular genetic mapping by BSA, together with molecular haplotyping for a functional Rpg5 gene and screening with rye stem rust, demonstrate that the TTKSK $R$ genes in the landrace and wild barley accessions map to the rpg4/Rpg5 region. Taken together, these data indicate that the TTKSK $R$ genes in the barley accessions are simply alleles of the rpg4/Rpg5 gene complex. Q21861 is the original source of the rpg4/Rpg5 gene complex and is one of the best-known accessions possessing a high level of adult plant resistance against race TTKSK. Several barley breeding programs in North America are introgressing rpg4/Rpg5 into elite breeding lines for resistance to race TTKSK. However, future work should be done to identify additional sources of resistance so that barley cultivars can be developed with a broad spectrum of resistance to $P$. graminis $\mathrm{f}$. sp. tritici races, including race TTKSK and its variants.

\section{ACKNOWLEDGMENTS}

This study was supported, in part, by funds provided through a grant from the Bill \& Melinda Gates Foundation and the UK Department for International Development to Cornell University for the Borlaug Global Rust Initiative Durable Rust Resistance in Wheat Project; the LiebermanOkinow Endowment at the University of Minnesota; American Malting Barley Association; and United States Department of AgricultureAgricultural Research Service Specific Cooperative Agreement: Development of Stem Rust Resistant Barley for the Upper Midwest, Agreement Number 58-3640-0-648. We thank the Minnesota Supercomputing Institute for hosting a software utilized in analysis of data included in this publication.

\section{LITERATURE CITED}

1. Alsop, B. P. 2009 Linkage analysis and inheritance of multiple disease resistance in intra-specific wild $\times$ cultivated barley populations. Ph.D. dissertation, University of Minnesota, St. Paul.

2. Arora, D., Gross T., and Brueggeman, R. 2013. Allele characterization of genes required for rpg4-mediated wheat stem rust resistance identifies Rpg5 as the R-gene. Phytopathology 103:1153-1161.

3. Borovkova, I., Steffenson, B., Jin, Y., Rasmussen, J., Kilian, A., Kleinhofs, A., Rossnagel, B., and Kao, K. 1995. Identification of molecular markers linked to the stem rust resistance gene rpg4 in barley. Phytopathology $85: 181-185$.
4. Brueggeman, R., Druka, A., Nirmala. J., Cavileer, T., Drader, T., Rostoks, N., Mirlohi, A., Bennypaul, H., Gill, U., and Kudrna, D. 2008. The stem rust resistance gene Rpg5 encodes a protein with nucleotide-binding-site, leucine-rich, and protein kinase domains. Proc. Natl. Acad. Sci. USA 105:14970-14975.

5. Close, T., Bhat, P., Lonardi, S., Wu, Y., Rostoks, N., Ramsay, L., Druka, A., Stein, N., Svensson, J., and Wanamaker, S. 2009. Development and implementation of high-throughput SNP genotyping in barley. BMC Genomics 10:582.

6. Druka, A., Kudrna, D., Han, F., Kilian, A., Steffenson, B., Frisch, D., Tomkins, J., Wing, R., and Kleinhofs, A. 2000. Physical mapping of the barley stem rust resistance gene rpg4. Mol. Gen. Genet. 264:283-290.

7. Fan, J., Gunderson, K. L., Bibikova, M., Yeakley, J. M., Chen, J., Wickham, Garcia, E., Lebruska, L. L., Laurent, M., Shen, R., and Barker, D. 2006. Illumina Universal Bead Arrays. Methods Enzymol. 410:57-73.

8. Fan, J., Oliphant, A., Shen, R., Kermani, B., Garcia, F., Gunderson, K., Hansen, M., Steemers, F., Butler, S., Deloukas, P., Galver, L., Hunt, S., McBride, C., Bibikova, M., Rubano, T., Chen, J., Wickham, E., Doucet, D., Chang, W., Campbell, D., Zhang, B., Kruglyak, S., Bentley, D., Haas, J., Rigault, P., Zhou, L., Stuelpnagel, J., and Chee, M.S. 2003. Highly parallel SNP genotyping. Cold Spring Harb. Symp. Quant. Biol. 68:6978.

9. Fetch, T., Jr., Johnston, P., and Pickering, R. 2009. Chromosomal location and inheritance of stem rust resistance transferred from Hordeum bulbosum into cultivated barley (H. vulgare). Phytopathology 99:339-343.

10. Fox, S., and Harder, D. 1995. Resistance to stem rust in barley and inheritance of resistance to race QCC. Can. J. Plant Sci. 75:781-788.

11. GrainGenes. 2013. GrainGenes: A Database for Triticeace and Avena. Agricultural Research Service of the United States Department of Agriculture, Washington, DC. http://wheat.pw.usda.gov/GG2/index.shtml

12. Hodson, D. P., Grønbech-Hansen, J., Lassen, P., Alemayehu, Y., Arista, J., Sonder, K., Kosina, P., Moncada, P., Nazari, K., Park, R. F., Pretorius, Z. A., Szabo, L. J., Fetch, T., and Jin, Y. 2012. Tracking the wheat rust pathogens. Pages 11-22 in: Proc. Borlaug Global Rust Initiative 2012 Tech. Workshop, Beijing. R. McIntosh, ed.

13. Hyten, D. L., Smith, J. R., Frederick, R. D., Tucker, M. L., Song, Q., and Cregan, P. B. 2009. Bulked segregant analysis using the GoldenGate Assay to locate the locus that confers resistance to soybean rust in soybean. Crop Sci. 49:265-271.

14. Jedel P. 1990. A gene for resistance to Puccinia graminis f. sp. tritici in PI 382313. Barley Genet. Newslett. 20:43-44.

15. Jedel. P., Metcalfe, D., and Martens, J. 1989. Assessment of barley accessions PI 382313, PI 382474, PI 382915, and PI 382976 for stem rust resistance. Crop Sci. 29:1473-1477.

16. Jin, Y., and Singh, R. 2006. Resistance in US wheat to recent eastern African isolates of Puccinia graminis f. sp. tritici with virulence to resistance gene $\mathrm{Sr} 31$. Plant Dis. 90:476-480.

17. Jin, Y., Steffenson, B., and Miller, J. 1994. Inheritance of resistance to pathotypes QCC and MCC of Puccinia graminis f. sp. tritici in barley line Q21861 and temperature effects on the expression of resistance. Phytopathology 84:452-455.

18. Kleinhofs, A., and Graner, A. 2001. An integrated map of the barley genome. Pages 187-199 in: DNA-Based Markers in Plants. R. L. Phillips and I. K. Vasil, eds. Kluwer Academic Publishers, Dordrecht, The Netherlands.

19. Kolmer, J. A. 2001. Early research on the genetics of Puccinia graminis and stem rust resistance in wheat in Canada and the United States. Pages 51-82 in: Stem Rust of Wheat from Ancient Enemy to Modern Foe. P. D. Peterson, ed. The American Phytopathological Society, St. Paul, MN.

20. Mamo, B. E. 2013. Genetic Characterization of multiple disease resistance and agronomical/nutritional traits in Hordeum. Ph.D. dissertation, University of Minnesota, St. Paul.

21. McIntosh, R. A., Wellings, C. R., and Park, R. F. 1995. Wheat Rusts: An Atlas of Resistance Genes. CSIRO Publishing, East Melbourne, Victoria, Australia.

22. Michelmore, R. W., Paran, I., and Kesseli, R. V. 1991. Identification of markers linked to disease resistance genes by bulked segregant analysis: A rapid method to detect markers in specific genomic regions by using segregating populations. Proc. Natl. Acad. Sci. USA 88:9828-9832.

23. Miller, J. D., and Lambert, J. 1955. Variability and inheritance of reaction of barley to race 15B of stem rust. Agron. J. 47:373-377.

24. Moscou, M. J., Lauter, N., Steffenson, B., and Wise, R. P. 2011. Quantitative and qualitative stem rust resistance factors in barley are associated with transcriptional suppression of defense regulons. PLoS Genet. 7:e1002208.

25. Mukoyi, F., Soko, T., Mulima, E., Mutari, B., Hodson, D., Herselman, L., Visser, B., and Pretorius, Z. 2011. Detection of variants of wheat stem rust race Ug99 (Puccinia graminis f. sp. tritici) in Zimbabwe and Mozambique. Plant Dis. 95:1188.

26. Muñoz-Amatriaín, M., Moscou, M. J., Bhat, P. R., Svensson, J. T., Bartoš, 
J., Suchánková, P., Šimková, H., Endo, T. R., Fenton, R. D., and Lonardi, S. 2011. An improved consensus linkage map of barley based on flowsorted chromosomes and single nucleotide polymorphism markers. Plant Genome 4:238-249.

27. Nazari, K., Mafi, M., Yahyaoui, A., Singh, R. P., and Park, R. F. 2009. Detection of wheat stem rust (Puccinia graminis f. sp. tritici) race TTKSK (Ug99) in Iran. Plant Dis. 93:317.

28. Patterson, F., Shands, R., and Dickson, J. 1957. Temperature and seasonal effects on seedling reactions of barley varieties to three races of Puccinia graminis f. sp. tritici. Phytopathology 47:395-402.

29. Peterson, R. F., Campbell, A., and Hannah, A. 1948. A diagrammatic scale for estimating rust intensity on leaves and stems of cereals. Can. J. Res. 26:496-500.

30. Powers, L., and Hines, L. 1933. Inheritance of reaction to stem rust and barbing of awns in barley crosses. J. Agric. Res. 46:12.

31. Pretorius, Z., Bender, C, Visser, B., and Terefe, T. 2010. First report of a Puccinia graminis $\mathrm{f}$. sp. tritici race virulent to the $\mathrm{Sr} 24$ and $\mathrm{Sr} 31$ wheat stem rust resistance genes in South Africa. Plant Dis. 94:784.

32. Pretorius, Z., Singh, R., Wagoire, W., and Payne, T. 2000. Detection of virulence to wheat stem rust resistance gene Sr31 in Puccinia graminis. f. sp. tritici in Uganda. Plant Dis. 84:203.

33. Pretorius, Z., Szabo, L., Boshoff, W., Herselman, L., and Visser, B. 2012. First report of a new TTKSF race of wheat stem rust (Puccinia graminis $\mathrm{f}$. sp. tritici) in South Africa and Zimbabwe. Plant Dis 96:590.

34. Quarrie, S. A., Lazic-Jancic, V., Kovacevic, D., Steed. A., and Pekic, S. 1999. Bulk segregant analysis with molecular markers and its use for improving drought resistance in maize. J. Exp. Bot. 50:1299-1306.

35. Roelfs, A. P. 1982. Effects of barberry eradication on stem rust in the United States. Plant Dis. 66:177-181.

36. Roelfs, A. P. 1986. Development and impact of regional cereal rust epidemics. Page 129-159 in: Plant Disease Epidemiology: Population Dynamics and Management. K. J. Leonard and W. E. Fry, eds. Macmillan, New York.

37. Roelfs, A. P., Singh, R., and Saari, E. 1992. Rust Diseases of Wheat: Concepts and Methods of Disease Management. Centro Internacional de Mejoramiento de Maíz y Trigo (CIMMYT), Mexico, DF.

38. Rostocks, N., Ramsay, L., MacKenzie, K., Cardle, L., Bhat, P. R., Roose, M. L., Svensson, J. T., Stein, N., Varshney, R. K., Marshall, D. F., Graner, A., Close, T. J., and Waugh, R. 2006. Recent history of artificial outcrossing facilitates whole-genome association mapping in elite inbred crop varieties. Proc. Natl. Acad. Sci. USA 103:18656-18661.

39. Shands, R. 1939. Chevron, a barley variety resistant to stem rust and other diseases. Phytopathology 29:209-211.

40. Singh, R. P., Hodson, D. P., Huerta-Espino, J., Jin, Y., Njau, P., Wanyera, R., Herrera-Foessel, S.A., and Ward, R. W. 2008. Will stem rust destroy the world's wheat crop? Adv. Agron. 98:271-309.

41. Stakman, E. C., Stewart, D. M., and Loegering, W. Q. 1962. Identification of Physiological Races of Puccinia graminis f. sp. tritici.. U. S. Dep.
Agric. Agric. Res. Serv. Publ. No. E617.

42. Steffenson, B., Jin, Y., Brueggeman, R., Kleinhofs, A., and Sun, Y. 2009. Resistance to stem rust race TTKSK maps to the rpg4/Rpg5 complex of chromosome 5H of barley. Phytopathology 99:1135-1141.

43. Steffenson, B., Wilcoxson, R., and Roelfs, A. 1984. Inheritance of resistance to Puccinia graminis f. sp. secalis in barley. Plant Dis. 68:762763.

44. Steffenson, B. J. 1992. Analysis of durable resistance to stem rust in barley. Euphytica 63:153-167.

45. Steffenson, B. J., Miller, J. D., and Jin, Y. 1993. Detection of the stem rust resistance gene Rpg1 in barley seedlings. Plant Dis. 77:626-629.

46. Steffenson, B. J., Olivera, P., Roy, J. K., Jin, Y., Smith, K. P., and Muehlbauer, G. J. 2007. A walk on the wild side: Mining wild wheat and barley collections for rust resistance genes. Aust. J. Agric. Res. 58:532544.

47. Steffenson, B. J., Zhou, H., Chai, Y., and Grando, S. 2013. Vulnerability of cultivated and wild barley to African stem rust race TTKSK. Pages 243-255 in: Advance in Barley Sciences. Proc. 11th Int. Barley Genet. Symp. G. Zhang, C. Li, and X. Liu, eds. Zhejiang University Press, Hangzhou, China, and Springer, Berlin.

48. Stubbs, R., Prescott, J., and Dubin, H. 1986. Cereal Disease Methodology Manual. Centro Internacional de Mejoramiento de Maíz y Trigo (CIMMYT), Mexico, DF.

49. Sun, Y., and Steffenson, B. 2005. Reaction of barley seedlings with different stem rust resistance genes to Puccinia graminis. Can. J. Plant Pathol. 27:80-89.

50. Sun, Y., Steffenson, B. J., and Jin, Y. 1996. Genetics of resistance to Puccinia graminis f. sp. secalis in barley line Q21861. Phytopathology 86:1299-1302.

51. Visser, B., Herselman, L., Park, R. F., Karaoglu, H., Bender, C. M., and Pretorius, Z. A. 2011. Characterization of two new Puccinia graminis f. sp. tritici races within the Ug99 lineage in South Africa. Euphytica 179:119-127.

52. Wang, X., Richards, J., Gross, T., Druka, A., Kleinhofs, A., Steffenson, B., Acevedo, M., and Brueggeman, R. 2013. The rpg4-mediated resistance to wheat stem rust (Puccinia graminis) in barley (Hordeum vulgare) requires Rpg5, a second NBS-LRR gene, and an actin depolymerization factor. Mol. Plant-Microbe Interact. 26:407-418.

53. Wanyera, R., Kinyua, M., Jin, Y., and Singh, R. 2006. The spread of stem rust caused by Puccinia graminis f. sp. tritici, with virulence on $\mathrm{Sr} 31$ in wheat in Eastern Africa. Plant Dis. 90:113-113.

54. Wolday, A., Fetch, T., Hodson, D., Cao, W., and Briere, S. 2011. First report of Puccinia graminis f. sp. tritici races with virulence to wheat stem rust resistance genes Sr31 and Sr24 in Eritrea. Plant Dis. 95:15911591.

55. Zhou, H., Steffenson, B. J., Muehlbauer, G., Wanyera, R., Njau, P., and Ndeda, S. 2014. Association mapping of stem rust race TTKSK resistance in US barley breeding germplasm. Theor. Appl. Genet. 127:1293-1304. 